\title{
ASSESSMENT OF SOIL PHYSICAL CHARACTERISTICS OF LUVISOLS UNDER MONOCULTURE OF VINES
}

\author{
Vladimír ŠIMANSKÝ*, Marek KOLENČÍK \\ Slovak University of Agriculture in Nitra, Slovak Republic
}

\begin{abstract}
The physical properties of Luvisols under vineyards of the Nitra wine-growing area (Slovakia) were evaluated in the paper. Soil samples were taken from two selected localities (Nitra - Dražovce, Vráble). The obtained results showed that in the soil profile of Dražovce, the average contents of non-capillary pores, capillary pores and semi-capillary pores to the total porosity were equal to 26.1, 64.4 and 9.4\%, respectively, and in the soil profile of Vráble - 22.3, 75.6 and 2.1\%, respectively. In the Dražovce locality, the average content of aggregate stability index $(S w)$ decreased in the following order: abandoned vineyard > grassy strip between the vineyard rows > intensively cultivated rows of vineyard. In contrast, in the Vráble locality, higher average contents of Sw were determined in intensively cultivated rows of vineyard in comparison to grassy strip between the vineyard rows. The lowest average value of vulnerability coefficient $(K v)$ was observed in abandoned vineyard (Dražovce locality) and in both localities in grassy strip between the vineyard rows. Intensive cultivation of the vineyard rows resulted in higher vulnerability of soil structure. The values of maximum capillary capacity were almost the same in both soil profiles of Luvisols. A higher content of soil moisture was observed in the soil profile in the Vráble locality $(33.6 \pm 2.50)$ in comparison to the Dražovce locality (30.6 \pm 5.44$)$. Higher content of storage moisture was determined in the Vráble locality $\left(2,684 \mathrm{I} \mathrm{m}^{-2}\right)$ in comparison to the Dražovce locality $\left(2,450 \mathrm{I} \mathrm{m}^{-2}\right)$.
\end{abstract}

Keywords: porosity, soil structure parameters, the Nitra viticulture region, vineyards

In viticulture, attaining high quality grapes for winemaking is a priority for growers. Quality can also be related to the effects of "terroir", a term first established for French wines (Wilson, 1998). In the "Old World" wine industry, the concept of "terroir", is used to describe all aspects of the environment, geography, geology, and cultural practices that influence grape production. A key factor for economical and sustainable vine growing is to ensure the optimal soil conditions; therefore, the soil for vine growing has to be ideal. White (2009) identified the following key properties, with respect to the ideal soil for vine growing: soil depth, soil structure and water, soil strength, soil chemistry, and nutrient supply and soil organism. Viticulture is unusual in that it is often conducted on sites considered as unsuitable for most crops. Before the foundation of a future vineyard, winemakers have to proceed in a preventive manner and assess the suitability of the area. They highlighted in addition to chemistry mainly the physical properties of soils. For example, in this regard, it is important that vines have sufficient water to allow for adequate vine and berry growth, but excess amounts of water can lead to excess vigour and poor fruit composition and vine quality. At present, Slovakia is prone to droughts and soil droughts, which negatively affect crop production, including major field crops (Mati et al., 2011).

As mentioned above, the successful cultivation of the vine is related to the selection of appropriate soil and climatic conditions before the establishment of the vineyard. Not all soil types are suitable for cultivation of each grape variety. At present, Slovakia has 11,199 hectares of vineyards and only 8,856 hectares of them are productive (ŠÚ SR, 2014). In Slovakia, vineyards are now growing on a range of soils including Chernozems, Cambisols, Luvisols, Fluvisols, and Leptosols (Šimanský, 2011). Very suitable soils for the vine growing are also Luvisols which occupy the area of 286182 ha, accounting for $11.7 \%$ of agricultural land in Slovakia (Zaujec et al., 2009), but these soils have a range of growing conditions for plants due to their different physical, physicochemical and biological properties.

The objectives of the present study were:

1. to compare the physical properties of Luvisols in the Nitra vine region,

2. to evaluate the effect of different soil management practices on the structural condition of Luvisols under monoculture of vine.

\section{Material and methods}

During the year 2011, the soil surveys were carried out to determine the soil properties of several vineyards soils in Nitra-Dražovce and Vráble. These localities are located in the Nitra vine-growing region (Slovakia) and there are different parent materials and climate conditions. Mean annual temperatures in the studied area ranged from 9.3 to $9.7^{\circ} \mathrm{C}$ and mean annual precipitation varied from 564 to $580 \mathrm{~mm}$. 
Both localities are categorized into the area of Podunajská nížina (also called the Danube Lowland, Slovakia) and has nature divided into finger like bays (Rybár et al., 2015). From geomorphological point of view, Dražovce belongs to the Nitra Upland. This locality (Dražovce) is tectonically divided from the right side on the Tribeč Mts. which is situated to the Western Carpathian Core Mountains with their Mesozoic formation (sequences) along to the Nitra Upland (Rišnovce Depression) on the left side (Pristáš et al., 2000). General orientation of these complex structures is $\mathrm{N}-\mathrm{S}$ direction. Geological background (Dražovce locality) is situated on intersect of these two entities and called Stredonitrianska field. Gradual origin and development of this locality was concentrated on formation of various erosion-accumulation structures e.g. multiple river terraces, alluvial cone coming from the Tribeč Mts. (Stankoviansky et al., 2012). Geomorphological design has been recently developed because of extensive anthropogenic performance mainly associated with agricultural "vineyard" activity. For development of material compositions of soil, considerable influence is posed by the fluvial terrace accumulation and their lateral movements or gravitationally transported materials from Mesozoic sequences (many carbonates components from the Tribeč Mts.) (Pristáš et al., 2000). The Vráble locality belongs to the geomorphological region of the Nitra and Žitava Uplands with the most typical of north-eastern part of the Danube Lowland (Šujan and Rybár, 2014). For the soil development of this locality, the Western Carpathian Core Mountain (the Tribeč Mts.) has no extensive impact on material composition as compared to the Dražovce area but specific development of multiple river terraces materials was detected. At this locality, the development with different intensity of subsidence and certain lateral migration of rivers was observed (channel networks) (Stankoviansky et al., 2012; Šujan and Rybár, 2014). Due to this reason, the Vráble locality underlines erosion-accumulation formations (river/fluvial sediments) with typical development such as multiple river terraces (Harčár et al., 1988; Šujan and Rybár, 2014).

In each locality, before soil sampling a pit was excavated (in grassy strip between the vineyard rows) and the soils were classified according to the World Reference Base for Soil Resources (WRB, 2006) based on the whole-profile soil morphology. Soils in the Dražovce and Vráble locality were classified as Haplic Luvisol and Stagni-Haplic Luvisol, respectively. In the soil pits, the soil samples were collected (in triplicate) after $10 \mathrm{~cm}$ layers to a depth of $80 \mathrm{~cm}$ to cylinders with an inner diameter of $5 \mathrm{~cm}$ and height of $5 \mathrm{~cm}$. Determination of physical (pore size distributions), hydrophysical properties (soil moisture, storage moisture, maximum capillary water capacity, available water capacity, and retention water capacity) was then conducted using standard methods (Fiala et al., 1999).

The total porosity $(P)$ in percentage was calculated according to equation 1 :

$$
P=\frac{\rho_{s}-\rho_{d}}{\rho_{s}} \cdot 100
$$

where:

$$
\begin{array}{ll}
\rho_{s} & - \text { particle density }\left(\mathrm{g} \mathrm{cm}^{-3}\right) \\
\rho_{d} & - \text { bulk density }\left(\mathrm{g} \mathrm{cm}^{-3}\right)
\end{array}
$$

Volume of non-capillary pores $(P n)$ in percentage was calculated according to the equation 2 :

$$
P n=P-\Theta_{30}
$$

where:

$$
\begin{array}{ll}
P & - \text { total porosity (\%) } \\
\Theta_{30^{\prime}} & - \text { soil moisture after } 30 \text { min of suction (\%) }
\end{array}
$$

Volume of the capillary pores $(P k)$ is identical to the water holding capacity $\left(\Theta_{R V K}\right)$ and volume of semi-capillary pores $(P s)$ in percentage was calculated according to the equation 3 :

$$
P S=\Theta_{30^{\prime}}-\Theta_{R V K}
$$

Soil moisture was assessed as gravimetric soil moisture expressed in percentage (\%) and then recalculated on volume percentage according to equation (4):

$$
\theta=w \times \rho
$$

where:

$\theta \quad$ - soil moisture by volume (\%)

w $\quad$ - soil moisture by weight (\%)

$\rho \quad$ - bulk density $\left(\mathrm{g} \mathrm{cm}^{-3}\right)$

The storage moisture (Ws) in percentage was calculated according to equation (5):

$$
W s=\theta \times h
$$

where:

$h \quad$ - thickness of the soil layer (dm)

The available water capacity (AWC) in percentage was calculated according to equation (6):

$$
A W C=\theta_{F C}-\theta_{w p}
$$

where:

$\theta_{F C} \quad$ - field capacity (\%)

$\theta_{w p} \quad$ - wilting point (\%)

The available water storage (AWs) in percentage was calculated according to equation (7):

$$
A W s=\theta-\theta_{w p}
$$

The soil samples for determination soil structure parameters (vulnerability coefficient, index of aggregate stability and crust index) were taken from a depth of $0-30 \mathrm{~cm}$ :

A/ In the Dražovce locality from three plots:

1. abandoned vineyard,

2. grassy strip between the vineyard rows,

3. intensive cultivated rows of the vine.

B/ In the Vráble locality from two plots:

1. grassy strip between the vineyard rows,

2. intensive cultivated rows of the vine. 
The vulnerability coefficient $(K v)$ was calculated according to following equation (8).

$$
K v=\frac{M W D_{d}}{M W D_{w}}
$$

where:

$M W D_{d}$-the mean weight diameter of aggregates for dry sieving $(\mathrm{mm})$

$M W D_{w}$-the mean weight diameter of WSA (mm)

The index of crusting $(I c)$ as well as the indexes of aggregate stability $(S w)$ were calculated according to following equations (9-10):

$$
I c=\frac{1.5 S_{f}+0.75 S_{c}}{C I+(10 \cdot S O M)}
$$

where:

$S_{f} \quad-\%$ fine silt

$S_{c} \quad-\%$ coarse silt

Cl - \% clay

SOM - \% soil organic matter content

$$
S W=\frac{W S A-0.09 \text { sand }}{\text { silt }+ \text { clay }}
$$

where:

WSA - is content of water-stable aggregates (\%)

For both localities, soil mineralogical composition was identified using $X$-ray diffraction analysis methodology according to González et al. (2007). In order to visualize physical quantities of clay minerals VESTA programme was evaluated (Momma and Izumi, 2011).

A simple $t$-test was carried out to test the significance between the physical properties in different soil profiles in the same soil type. The interrelations between pore size distributions and soil water parameters in soil profiles of Luvisols were determined through correlation matrix. Above-mentioned statistical analysis was performed using the computer program Statgraphics Centurion XV.I (Statpoint Technologies, Inc., USA).

\section{Results and discussion}

In both soil profiles, the pore size distributions are shown in Figure 1 A, B. Overall, in soil profiles of Luvisols to the depth $80 \mathrm{~cm}$ the values of total porosity $(P)$, capillary pores $(P k)$ as well as non-capillary pores $(P n)$ were on average the same, however, within each of studied soil profiles, porosity distribution was different across the depth. The average vineyard soils of Slovakia (Šimanský et al., 2013; Šimanský et al., 2016) but also abroad (Ruiz-Colmenero et al., 2013; Navel et al. 2014). In the Dražovce locality, the average content of aggregate stability index $(S w)$ decreased in the following order: abandoned vineyard > grassy strip between the vineyard rows $>$ and intensively cultivated rows of vineyard. The better structural state is often determined in-between

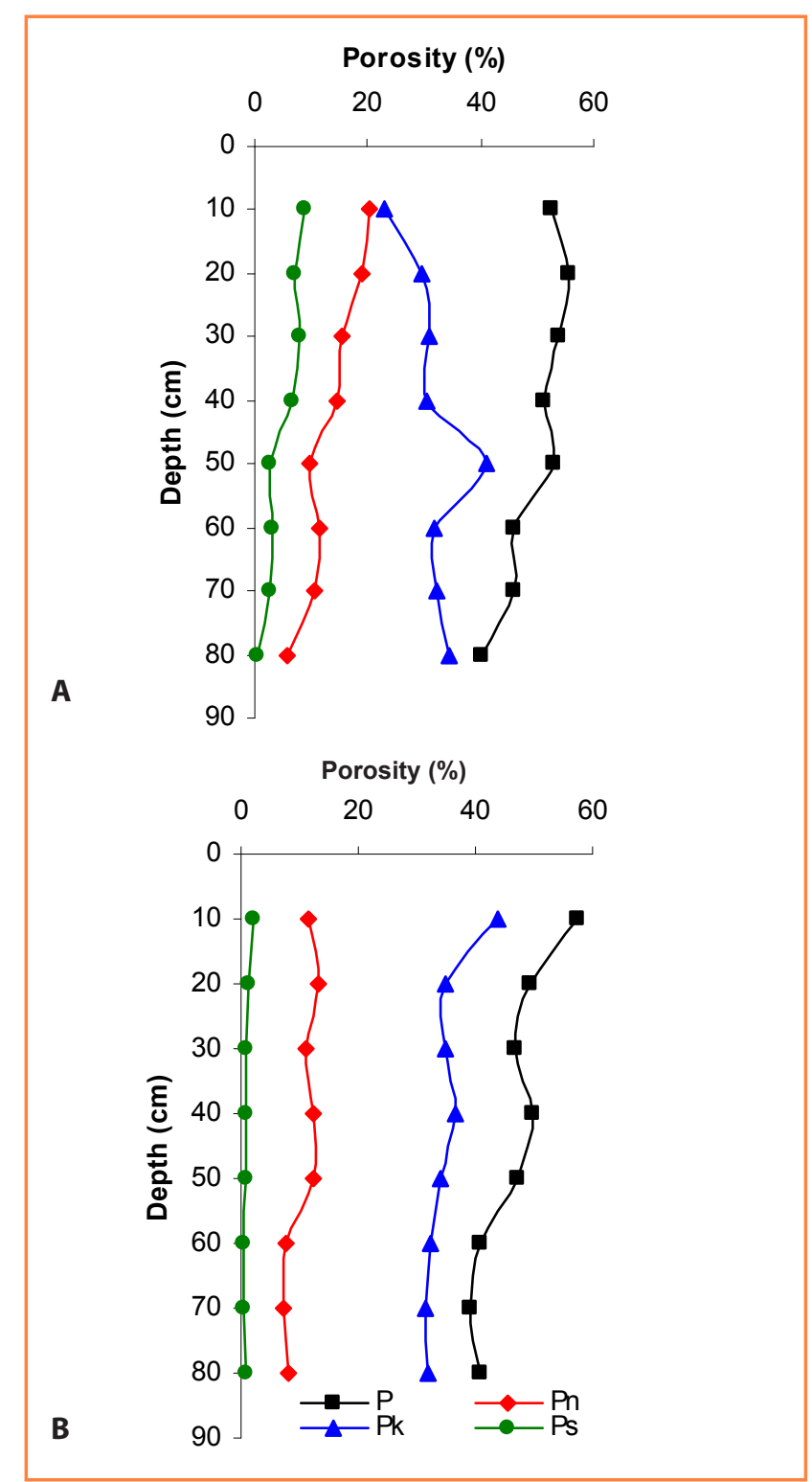

Figure 1 Pore size distributions in profiles of Luvisols A) in Dražovce locality and, B) in Vráble locality $P$ - total porosity, $P n$ - non-capillary pores, $P k$ - capillary pores, $P_{s}-$ semi-capillary pores

Table 1 Statistical evaluation of physical properties of Luvisols (comparison between two soil profiles of Luvisols, based on $t$-test)

\begin{tabular}{|l|c|c|c|c|c|c|c|c|}
\hline & $\boldsymbol{P}$ & $\boldsymbol{P n}$ & $\boldsymbol{P k}$ & $\boldsymbol{P s}$ & $\theta$ & $\boldsymbol{A W C}$ & $\boldsymbol{A W s}$ & $\theta \boldsymbol{K M} \boldsymbol{K}$ \\
\hline $\boldsymbol{t}$-test & 1.157 & 1.444 & -1.520 & 3.518 & -1.383 & -0.496 & -0.370 & -0.036 \\
\hline Probability & 0.267 & 0.171 & 0.151 & 0.003 & 0.188 & 0.628 & 0.717 & 0.972 \\
\hline
\end{tabular}

$P$ - total porosity, $P n$ - non-capillary pores, $P k$ - capillary pores, $P s-$ semi-capillary pores, $\theta$ - soil moisture, $A W C$ - available water capacity, AWs - available water storage, $\theta K M K$ - maximum capillary capacity 
Table 2 Parameters of structure stability and vulnerability in Luvisols

\begin{tabular}{|l|c|c|c|c|c|}
\hline \multirow{2}{*}{ Parameters } & \multicolumn{3}{|c|}{ Dražovce } & \multicolumn{2}{c|}{ Voíble } \\
\cline { 2 - 6 } & \multicolumn{3}{|c|}{ soil management } & management \\
\cline { 2 - 6 } & abandoned vineyard & cultivated rows & grass in the rows & cultivated rows & grass in the rows \\
\hline Kv & 1.34 & 6.54 & 1.66 & 4.75 & 0.81 \\
\hline Sw & 1.14 & 0.75 & 1.11 & 1.24 & 1.16 \\
\hline Ic & 0.91 & 1.23 & 1.02 & 1.30 & 0.63 \\
\hline
\end{tabular}

$K v-$ vulnerability coefficient, $S w$ - index of aggregate stability, $l c$ - crust index

Table 3 Correlation coefficients between pore size distributions and soil water parameters

\begin{tabular}{|l|c|c|c|c|c|c|c|c|}
\hline \multirow{2}{*}{ Parameters } & \multicolumn{4}{|c|}{ Dražovce } & \multicolumn{4}{c|}{ Vráble } \\
\cline { 2 - 9 } & $\theta$ & Ws & AWC & AWs & $\theta$ & Ws & AWC & AWs \\
\hline $\boldsymbol{P}$ & n.s. & n.s. & n.s. & n.s. & $0.840^{* * *}$ & $0.840^{* * *}$ & $0.904^{* * *}$ & $0.803^{*}$ \\
\hline $\boldsymbol{P n}$ & $-0.841^{* *}$ & $-0.841^{* *}$ & n.s. & $-0.736^{*}$ & n.s. & n.s. & n.s. & $0.726^{*}$ \\
\hline $\boldsymbol{P k}$ & $0.965^{* * *}$ & $0.965^{* * *}$ & $0.828^{*}$ & $0.809^{*}$ & $0.775^{*}$ & $0.775^{*}$ & $0.905^{* *}$ & $0.713^{*}$ \\
\hline $\boldsymbol{P s}$ & $-0.784^{*}$ & $-0.784^{*}$ & $-0.777^{*}$ & $-0.801^{*}$ & $0.711^{*}$ & $0.711^{*}$ & $0.838^{* *}$ & n.s. \\
\hline
\end{tabular}

$P>0.05=$ n.s.; ${ }^{*} P<0.05 ;{ }^{* *} P<0.01 ;{ }^{* * *} P<0.001$

$P$ - total porosity, $P n-$ non-capillary pores, $P k$ - capillary pores, $P s-$ semi-capillary pores, $\theta$ - soil moisture, $W s-$ storage moisture, $A W C$ - available water capacity, AWs - available water storage

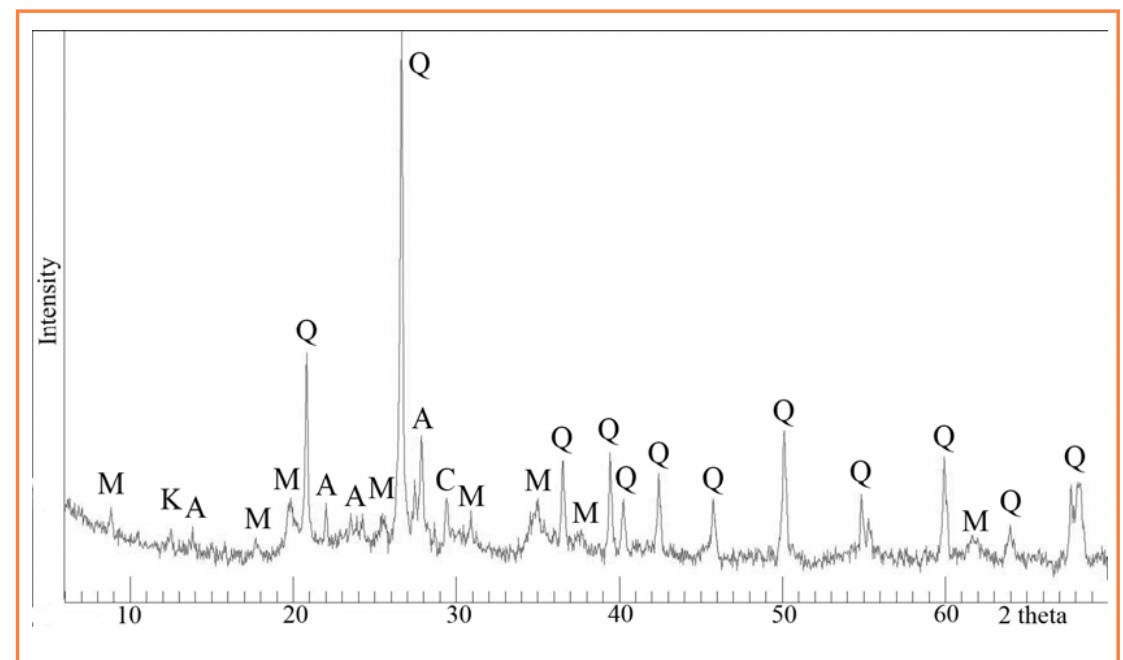

Figure 2 X-ray diffraction analysis of soil minerals in Drážovce locality: $\mathrm{Q}$ - quartz $\left(\mathrm{SiO}_{2}\right), \mathrm{A}$ - albite/ anortite $\left(\mathrm{NaCaAISi} \mathrm{O}_{8}\right), \mathrm{M}$ - muscovite $\left(\mathrm{KAl}_{2}\left(\mathrm{AlSi}_{3} \mathrm{O}_{10}\right)\right.$ $\left.(\mathrm{OH})_{2}\right), \mathrm{C}$ - calcite $\left(\mathrm{CaCO}_{3}\right)$ and $\mathrm{K}$ - kaolinite $\left(\mathrm{Al}_{2}\left(\mathrm{Si}_{2} \mathrm{O}_{5}\right)(\mathrm{OH})_{4}\right)$ with the minor content of clinochlore $\left(\left(\mathrm{Mg}, \mathrm{Fe}^{2+}\right) 5 \mathrm{Al}\left(\mathrm{Si}_{3} \mathrm{Al}\right) \mathrm{O}_{10}(\mathrm{OH})_{8}\right)$

content of $P n, P k$ and semi-capillary pores (Ps) was equal to 26.1, 64.4 and $9.4 \%$ in soil profile of Dražovce and $22.3,75.6$ and $2.1 \%$ to the total porosity in soil profile of Vráble. Statistical significant differences in $P s$ were determined between soil profiles of Luvisol (Table 1). Lal and Shukla (2004) indicated that the content of macro-pores, which also included non-capillary and semi-capillary pores depends on the soil management practices and the micro-pores are influenced by particle-size distribution of soil (Lipiec et al., 2006).
Soil aggregation affects many physical and physicochemical soil characteristics including porosity, water retention, and etc. (Czachor et al., 2015). Dal Ferro et al. (2012) attributed the presence of smaller pore sizes in soils to their greater water stability. An increased porosity can reduce aggregate stability (Czachor et al., 2015). Parameters of structure stability and vulnerability are summarized in Table 2. The structure parameters were dependent on the soil management practices in vineyards, which are consistent with several works in the rows of vineyard where the grass is planted than that in intensive cultivated vineyard soils (Šimanský et al., 2016). Opposite, in the Vráble locality the average contents of $\mathrm{Sw}$ were higher in intensively cultivated rows of vineyard in comparison to grassy strip between the vineyard rows. Optimal soil management practices can be responsible for a higher aggregate stability (Gonet et al., 2013). The lowest average value of vulnerability coefficient $(K v)$ was observed in abandoned vineyard (Dražovce locality) and in both localities in grassy strip between the vineyard rows. Intensive cultivation of the vineyard rows resulted in higher vulnerability of soil structure. The same effect was observed in the crusting index values. The highest formation of soil crust was determined in intensive cultivated rows of vineyards. The same results were published by Šimanský et al. (2014). This situation with soil crusting is impossible to explain by association with a SOM as well as clay because the SOM and clay are not correlated with $S w$ and $K v$ values. Soils dominated by variable charge clay minerals such as $1: 1$ clay and oxides have higher aggregation at lower SOC levels whereas soils with mixed mineralogy clays have higher aggregation at higher SOC (Denef et al., 2002). For 1 : 1 clay minerals with typical negative surface charge associated 


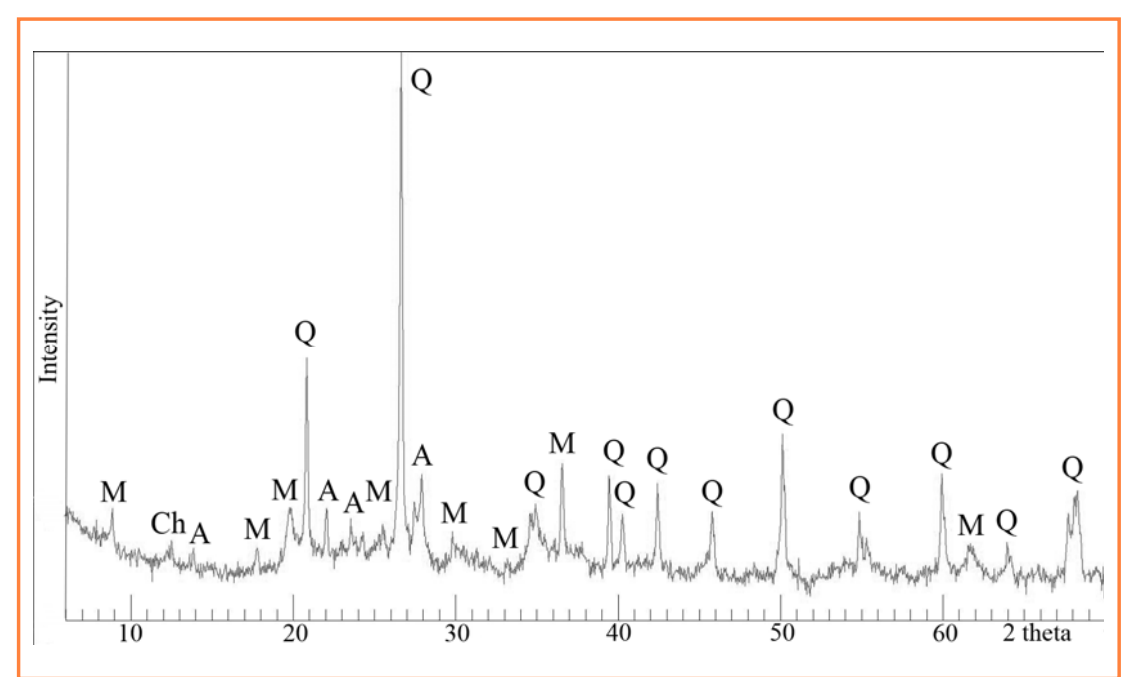

Figure 3 X-ray diffraction analysis of soil minerals in Vráble locality: $\mathrm{Q}$ - quartz $\left(\mathrm{SiO}_{2}\right), \mathrm{A}$ - albite-anortite $\left(\mathrm{NaCaAISi} \mathrm{O}_{8}\right), \mathrm{M}$ - muscovite $\left(\mathrm{KAl}_{2}\left(\mathrm{AlSi}_{3} \mathrm{O}_{10}\right)\right.$ $\left.(\mathrm{OH})_{2}\right)$, and $\mathrm{Ch}$ - clinochlore $\left(\left(\mathrm{Mg}, \mathrm{Fe}^{2+}\right) 5 \mathrm{Al}\left(\mathrm{Si}_{3} \mathrm{Al}\right) \mathrm{O}_{10}(\mathrm{OH})_{8}\right)$ there was also detected low content of kaolinite $\left(\mathrm{Al}_{2}\left(\mathrm{Si}_{2} \mathrm{O}_{5}\right)(\mathrm{OH})_{4}\right)$

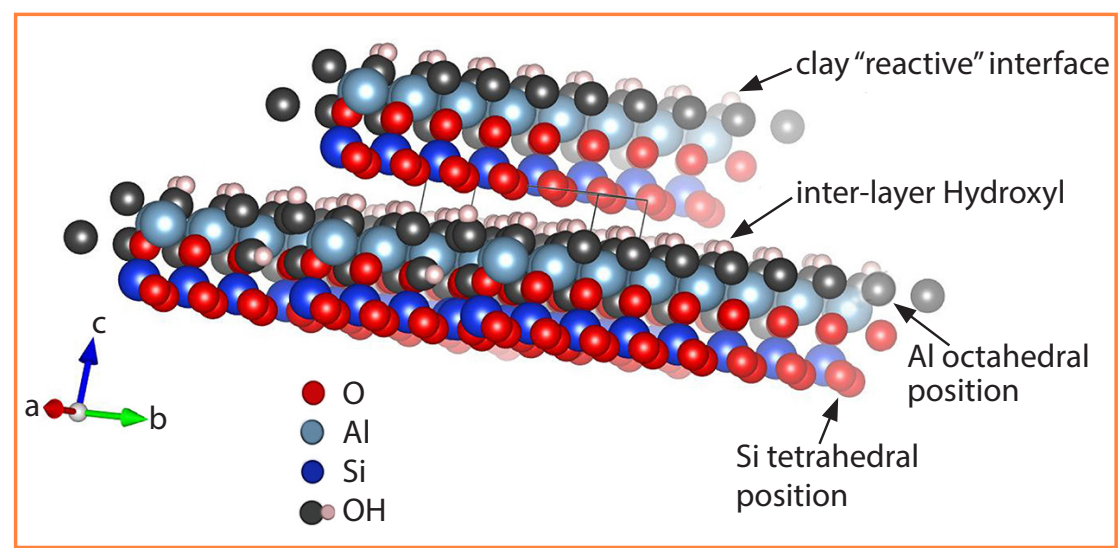

Figure 4 Model of phyllosilicate structure (multi-layered clay mineral) e.g. kaolinite (type of $1: 1$ ) with visualised octahedral and tetrahedral sheets, interlayered dimension along with active surface determined different charge, water supply, and etc. in clay structures; $a, b, c$ - axes shown main vectors integrity

with quartz which predominantly has positive charge it is most likely mineral-mineral bonding (Denef et al., 2004). Generally, soils which contain 2 : 1 clay minerals (two octahedral and one tetrahedron layers) play a key role to develop the aggregates with long-term stability because of higher cation exchange capacity and specific surface area. These properties have tendency to strong interactions with organic substances and more clays minerals (Vitro, et al. 2013). The parameters of SOM from studied localities are mentioned by Šimanský et al. (2016). In the Dražovce locality, the total SOC content was the lowest in cultivated rows of vine $(0.98 \%)$ then follows grass in the rows of vine phillosilicate with extensive element substitution (the same or different element valence substitutions) ability with strong impact on soil structure and other soil characteristics (Denef et al., 2004; Vitro et al. 2013). It is most probable that the existence of other layered phillosilicates (clay), and other minerals in the system could play a role contributing to a gradual aggregate formation and stability (Denef et al. 2004). In the Vráble locality, the SOC content was more than two times higher under grasses $(2.17 \%)$ than without grasses $(0.88 \%)$. This locality has almost similar association of soil minerals (as compared to the Drážovce locality) such as quartz, albite-anortite, muscovite without a higher content of calcite but with a great content of mixed clay minerals (multi-layered phillosilicates) that was detected from chloride group - clinochlore (Figures 3 , phillosilicate type $2: 1$ ). This result suggested that clay minerals with variable charge such as kaolinite (1: 1) type (Drážovce locality) along with quartz has higher aggregate stability by lower SOC $(0.98 \%)$, than soils in the Vráble locality with mixed clay minerals such as clinochlore (2: 1 type) that needed higher SOC $(2.17 \%)$ to aggregate formation. Similar results of clay like minerals were also confirmed in soils by Denef et al. (2004), and Virto et al. (2013).

The retention capacity of soils was assessed on the basis of capillary pores. In all cases, the results of $P k$ content showed a high capacity of the soils to retain water within the soil profiles. The values of maximum capillary capacity were almost the same in both profiles of Luvisols. On average, the values were $35.2 \%$ and $35.3 \%$ in the Dražovce locality and the Vráble locality, respectively. Based on the $t$-test results, statistically significant differences in the soil moisture content between both soil profiles of Luvisols were not observed (Table 1), however, on average, a higher content of soil moisture by $10 \%$ was observed in soil profile in the Vráble locality $(33.6 \pm 2,50 \%)$ in comparison to the Dražovce locality (30.6 $\pm 5.44 \%)$. Values of storage moisture (Ws) showed similar differences. Ws values reflect the soil water content in the soil layer at the time of collection (Fulajtár, 2006). A higher content of Ws was 


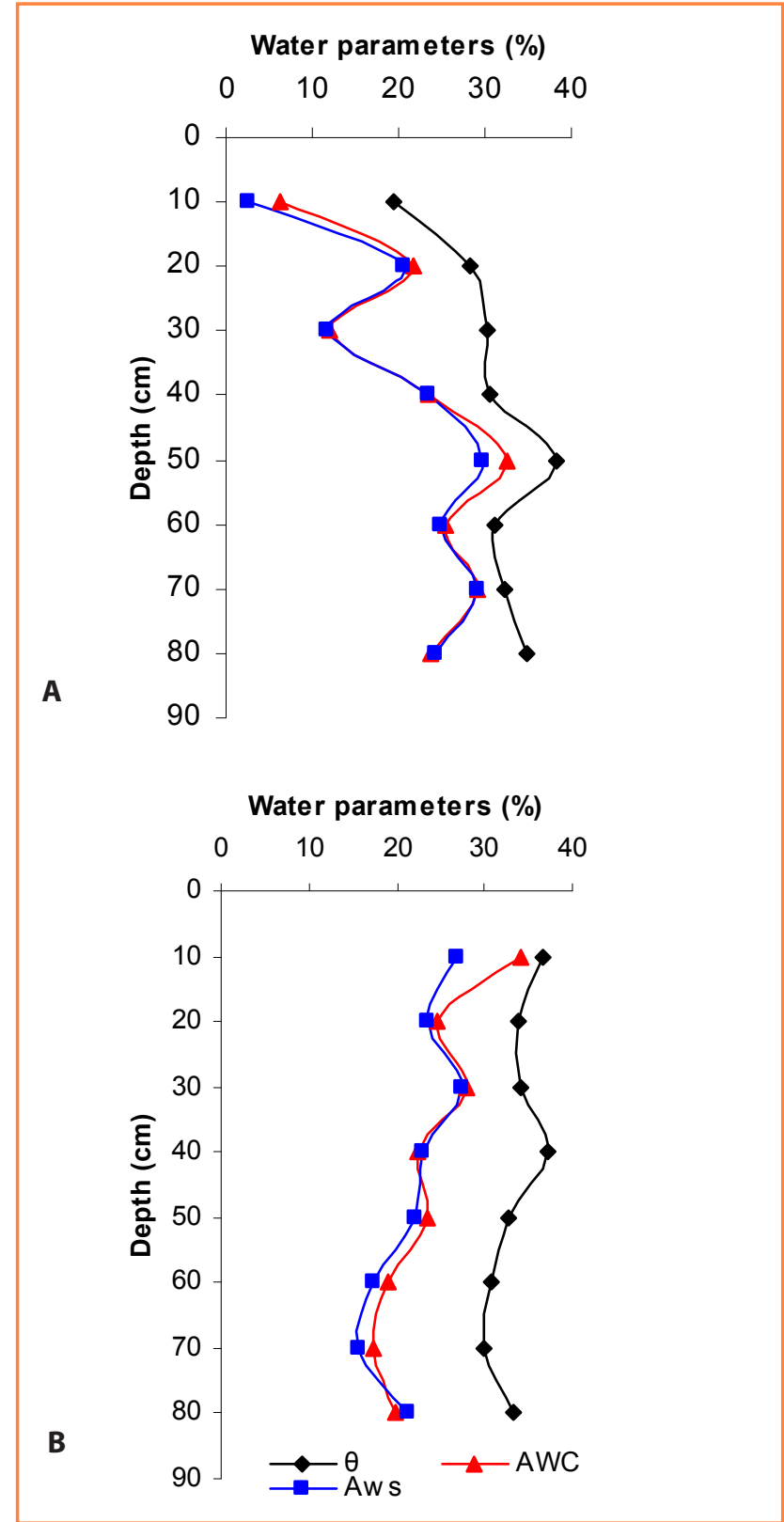

Figure 5 Water parameters in profiles of Luvisols A) in Dražovce locality and, B) Vráble locality

$\theta$ - soil moisture, AWC - available water capacity, AWs available water storage

determined in the Vráble locality $\left(2,684 \mathrm{I} \mathrm{m}^{-2}\right)$ in comparison to the Dražovce locality $\left(2,450 \mathrm{I} \mathrm{m}^{-2}\right)$, however, the trends of changes due to the soil depth were different (Figure $5 \mathrm{~A}, \mathrm{~B}$ ). The same effects in linear trends were observed in available water capacity $(A W C)$ in both soil profiles of Luvisols. In the Dražovce locality, the values of $A W C$ linearly increased within the soil depth $\left(y=1.99 x+1.67 ; R^{2}=0.493\right)$ and opposite, in the Vráble locality, the values of AWC linearly decreased within the soil depth $\left(y=-3.91 x+137.23 ; R^{2}=0.751\right)$. Statistically significant differences in the AWC $(t=-0.496, P=0.628)$ in both soil profiles of Luvisols were not observed. The AWC can be influenced by field water capacity and by wilting point (Fulajtár, 2006). The retention water capacity and wilting point are influenced by particle-size distribution. Soils with higher clay content have a higher retention capacity than sandy soils. The mentioned soils had been evaluated according to WRB classification as medium (WRB, 2006) with average clay content of $20 \%$ to the soil depth of $30 \mathrm{~cm}$. The clay particles are able to be located nearby plant roots (Tisdall and Oades, 1982) and the root system of plants has a higher amount of available water. On the other hand, plants with a higher ground biomass have more requirements in water and AWC can be limited. Šimanský and Bajčan (2013) showed that soil management practices in a productive vineyard had a statistically significant influence on values of $A W C$. Statistically significant differences in the available water storage $(A W s)(t=-0.370, P=0.717)$ in both soil profiles of Luvisols were not observed, however, the changes due to the soil depth in both profiles were significant. In the Dražovce locality, the values of $A W s$ linearly increased within the soil depth $\left(y=2.02 x+3.03 ; R^{2}=0.577\right)$ and, in contrast, in the locality the values of $A W s$ linearly decreased within the soil depth $\left(y=-4.71 x+149.3 ; R^{2}=0.615\right)$.

Table 3 shows the coefficients of correlations between porosity and water availability. In the locality Vráble, we determined statistically significant correlations between total porosity and other water parameters. An opposite situation was observed in the Dražovce locality. The negative significant correlations were observed between the $P n$ and $\theta$, Ws and $A W s$, but only in soil profile of the Dražovce locality. It means that the higher of $P n$ in soil was, the lesser was the decrease in soil water parameters. In both soil profiles, the higher $P k$ contents resulted in higher values of soil water parameters. The higher content of $P s$ in soil there was the higher values of $\theta$, Ws and AWC were but only in the Vráble locality. On the other hand, content of Ps in soil resulted in lower values of soil water parameters in the Dražovce locality.

\section{Conclusion}

Even though both soil profiles of Luvisols differed in physical characteristics mainly across the depth, they had high capacity to retain water within the soil profiles on average. The same, the values of maximum capillary capacity, storage moisture, available water capacity and available water storage were almost the same on average in both profiles of Luvisols. The lowest vulnerability of soil structure was observed in abandoned vineyards and in both localities in grassy strip between the vineyard rows. Intensive cultivation of the vineyard rows resulted in higher vulnerability of soil structure. The same effect was observed in the crusting index values. The highest formation of soil crust was determined in intensive cultivated rows of vineyards. Soil management practices significantly influenced soil structure and our results supported the importance of optimization of soil management practices in productive vineyards to avoid the environmental degradation and to maintain the sustainable land management of Luvisols which are suitable soils for growing vines.

\section{References}

CZACHOR, H. - CHARYTANOWICZ, M. - GONET, S. - NIEWCZAS, J. JOZEFACIUK, G. - LICHNER, L. 2015. Impact of long-term mineral and organic fertilizer application on the water stability, wettability and porosity of aggregates obtained from two loamy soils. In 
Europen Journal of Soil Science, vol. 66, 2015, no. 3, pp. 1-2. DAL FERRO, N. - BERTI, A. - FRANCIOSO, O. - FERRARI, E. MATTHEWS, G.P. - MORARI, F. 2012. Investigating the effects of wettability and pore size distribution on aggregate stability: the role of soil organic matter and humic fraction. In Europen Journal of Soil Science, vol. 63, 2012, pp. 152-164.

DENEF, K. - SIX, J. - MERCKX, R. - PAUSTIAN, K. 2002. Short-term effects of biological and physical forces on aggregate formation in soils with different clay mineralogy. In Plant Soil, vol. 246, 2002, pp. 185-200.

DENEF, K. - SIX, J. - MERCKX, R. - PAUSTIAN, K. 2004. Carbon Sequestration in Microaggregates of No-Tillage Soils with Different Clay Mineralogy. In Soil Sci. Soc. Am. J., vol. 68, 2004, pp. 1935-1944. FIALA, K. - KOBZA, J. - MATUŠKOVÁ, L. - BREČKOVÁ, V. MAKOVNÍKOVÁ, J. - BARANČÍKOVÁ, G. - BÚRIK, V. - LITAVEC, T. HOUŠKOVÁ, B. - CHROMANIČOVÁ, A. - VÁRADIOVÁ, D. - PECHOVÁ, B. 1999. Valid Methods of Soil Analyses. Partial monitoring system Soil (in Slovak). Bratislava :VÚPOP, 1999. 142 p. ISBN 80-85361-55-8. FULAJTÁR, E. 2006. Physical properties of soil (in Slovak). Bratislava : VÚPOP, 2006, 40 p. ISBN 80-89128-20-3.

GONET, S.S. - CZACHOR, H. - MARKIEWICZ, M. 2013. Organic carbon and humic substances fractions in soil aggregates. In $\mathrm{Xu}, \mathrm{J}$. - Wu, J. - He, Y. (eds.) Functions of natural organic matter in changing environment, Springer, 2013. pp. 215-217.

GONZÁLEZ, C. - QUINTANAM J.R. - MORENO, L. - VÁZQUEZ, A. LAFUENTE, A.L. - ROMERO, A. 2007. Applying multivariate methods to soil-solution interactions in carbonate media. In Geoderma, vol. 137, 2007, pp. 352-359.

HARČÁR, J. - PRIECHODSKÁ, Z. - KAROLUS, K. - KAROLUSOVÁ, E. REMŠÍK, A. - ŠUCHA, P. 1988. Explanations to the geological map of the north-eastern part of the Podunajská lowland (in Slovak). Bratislava : State geological institute of Dioníz Štúr, 1988. 114 p.

LAL, R.- SHUKLA, M.K. 2004. Principles of soil physics. New York : Marcel Dekker, 2004. 716 p. ISBN 0-8247-5324-0.

LIPIEC, J. - KUS, J. - SLOWINSKA-JURKIEWICZ, A. - NOSALEWICZ, A. 2006. Soil porosity and water infiltration as influenced by tillage methods. In Soil Tillage Res., vol. 89, 2006, pp. 210-220.

MATI, R. - KOTOROVÁ, D. - GOMBOŠ, M. - KANDRA, B. 2011 Development of evapotranspiration and water supply of clayloamy soil on the East Slovak Lowland. In Agricultural Water Management, vol. 98, 2011, pp. 1133-1140.

MOMMA, K. - IZUMI, F. 2011. VESTA 3 for three-dimensional visualization of crystal, volumetric and morphology data. In Journal of Applied Crystallography, vol. 44, 2011. pp. 1272-1276.

NAVEL, A. - MARTINS, J.M.F. 2014. Effect of long term organic amendments and vegetation of vineyard soils on the microscale distribution and biogeochemistry of copper. In Science of the Total Environment, vol. 466, 2014, pp. 681-689.

PRISTÁŠ, J. - ELEČKO, M. - MAGLAY, J. - FORDINÁL, K. - ŠIMON, L. GROSS, P. - POLÁK, M. - HAVRILA, M. - IVANIČKA, J. - HATÁR, J. VOZÁR, J. - TKÁČOVÁ, H. - TKÁČ, J. - LIŠČÁK, P.- JÁNOVÁ, V. - ŠVASTA, J. - REMŠÍK, A. - ŽÁKOVÁ, E. - TÖROKÖVÁ, I. 2000: Explanatory notes to geological map of the Danube Lowland - Nitrianska Pahorkatina Upland 1:50 000 (in Slovak). Bratislava : State geological institute of Dioníz Štúr, 2000. 250 p. ISBN 80-88974-26-7.
RUIZ-COLMENERO, M. - BIENES, R. - ELDRIDGE, D.J. - MARQUES, M.J. 2013. Vegetation cover reduces erosion and enhances soil organic carbon in a vineyard in the central Spain. In Catena, vol. 104, 2013, pp. 153-160.

RYBÁR, S. - HALÁSOVÁ, S. - HUDÁČKOVÁ, N. - KOVÁČ, M. KOVÁČOVÁ, M. - ŠARINOVÁ, K. - ŠUJAN, M. 2015. Biostratigraphy, sedimentology and paleoenvironments of the northern Danube Basin: Ratkovice 1 well case study. In Geologica Carpatica, vol. 66, 2015, no. 1, pp. 51-67.

ŠIMANSKÝ, V. 2011. Soil and nutrition of vine (in Slovak). Nitra : SPU, 2011. 46 p. ISBN 978-80-552-0565-6.

ŠIMANSKÝ, V. - POLLÁKOVÁ, N. - HALMO, S. 2014. Soil crust in agricultural land. In Acta fytotechnica et zootechnica, vol. 17, 2014, no 4, pp. 109-114.

ŠIMANSKÝ, V. - BAJČAN, D. - DUCSAY, L. 2013. The effect of organic matter on aggregation under different soil management practices in a vineyard in an extremely humid year. In Catena, vol. 101, 2013, p. 108-113.

ŠIMANSKÝ, V. - BAJČAN, D. 2013. The response of different soil management practices in a vineyard to water availability. In Acta fytotechnica et zootechnica, vol. 16, 2013, no. 3, p. 53-57.

ŠIMANSKÝ, V. - BALASHOV, E. - HORÁK, J. 2016. Water stability of soil aggregates and their ability to sequester carbon in soils of vineyards in Slovakia. In Archives of Agronomy and Soil Science, vol. 62, 2016, no. 2, pp. 177-197.

STANKOVIANSKY, M. - BARKA, I. - BELLA, M. - BOLTIŽIAR, M. GREŠKOVÁ, A. - HÓK, P. - IŠTOK, P. - LEHOTSKÝ, M. - MICHALKOVÁ, M. - MINÁR, J. - ONDRÁŠIK, M. - ONDRÁŠIK, R. - PECHO, J. PIŠÚT, P. - TRIZNA, M. - URBÁNEK, J. 2012. Recent landform evolution in Slovakia. Springer Netherlands, 2012. 175 p. ISBN 978-94-007-2447-1.

ŠUJAN, M. - RYBÁR, S. 2014. The development of Pleistocene river terraces in the eastern part of the Danube Basin (in Slovak). In Acta geologica slovaca, vol. 6, 2014, no. 2, pp. 107-122.

ŠÚ SR. 2014. Statistical Office of the Slovak Republic. www.statistics.sk TISDALL, J.M. - OADES, J.M. 1982. Organic matter and water-stable aggregates in soils. In J. Soil. Sci., vol. 33, 1982, pp. 141-163.

VIRTO, I. - FERNÁNDEZ-UGALDE, O. - BARRÉ, P. - IMAZ, M.J. ENRIQUE, A. - BESCANSA, P.-POCH, R.M. 2013. Micromorphological analysis on the influence of the soil mineral composition on shortterm aggregation in semi-arid Mediterranean soils. In Spanish Journal of Soil Science, vol. 3, 2013, no. 2, pp. 116-129.

WILSON, J. E. 1998. Terroir: the role of geology, climate, and culture in the making of French wines. London : Mitchell Beazley, 1998. 336 p. ISBN 1-84-000033-3.

WHITE, R. E. 2009. Understanding Vineyard Soils. New York : Oxford University Press, 2009. 217 p. ISBN 978-0-19-531125-9.

WRB. 2006. World reference base for soil resources. World Soil Resources Reports no. 103. Rome, FAO, 2006. 103 p. ISBN 978-0-19-531125-9.

ZAUJEC, A. - CHLPÍK, J. - NÁDAŠSKÝ, J. - SZOMBATHOVÁ, N. TOBIAŠOVÁ, E. 2009. Pedology and principles of geology (in Slovak). Nitra : SUA, 2009. 217 p. ISBN 978-80-552-0207-5. 